\title{
A PRELIMINARY STUDY OF STRESS FRACTURES AMONG PARAMILITARY TRAINEES
}

Prasanna C1, Vijay Baba N², Rajinikanth S³

\section{HOW TO CITE THIS ARTICLE:}

Prasanna C, Vijay Baba N, Rajinikanth S. "A Preliminary Study of Stress Fractures among Paramilitary Trainees". Journal of Evolution of Medical and Dental Sciences 2014; Vol. 3, Issue 10, March 10; Page: 2565-2569, DOI: $10.14260 /$ jemds/2014/2174

ABSTRACT: Stress fractures are common overuse injuries. The pathogenesis is multifactorial and usually involves repetitive sub-maximal stresses. Stress fractures have been frequently reported among young military recruits and in sports persons, but to our knowledge they have not been studied among the paramilitary trainees. The present study was carried out at the Central Industrial Security Force training center at Arakkonam, Tamilnadu from March 2010 to May 2012 to find the incidence of stress fractures among fresh trainees. All patients presenting with symptoms suggestive of stress fractures were evaluated. A total of 5 cases out of a total of 2000 trainees $(0.25 \%)$ were confirmed as stress fractures based on clinical and radiological findings.

KEYWORDS: Stress fractures, Paramilitary Trainees.

INTRODUCTION: A stress fracture is the response of bone to repeated stress, none of which by itself is sufficient to cause a fracture. Stress fractures represent one of the most common and potentially serious injuries. ${ }^{1-3}$ Stress fractures occur among persons with normal bones and no acute injury who are undergoing physical activity to which they are unaccustomed ${ }^{4-6}$ the underlying pathophysiology is believed to relate to repetitive mechanical loading of bone secondary to physical activity that stimulates an incomplete remodeling response. ${ }^{7-9}$

Stress fractures are traditionally been described in military recruits, but are also seen in sports persons. However they are known to occur in anyone being exposed to a level of physical stress or activity to which he or she is not adapted. ${ }^{10} \mathrm{~A}$ literature search revealed that stress fractures are extensively studied in army recruits and sports persons, but not in paramilitary personnel. Even though the amount of training varies between military and paramilitary trainees, they are also exposed to a high level of physical training to which they are unaccustomed. Hence the present study was initiated with an aim to find out the incidence of stress fractures among the paramilitary trainees

MATERIALS AND METHODS: The study was conducted among the paramilitary trainees at central industrial security forces (CISF) training centre, Arakkonam, Tamilnadu, India. The study period was from March 2010 to May 2012 (27 Months). Approximately 2, 000 trainees were trained at the centre during the study period. All the trainees were males and were in the age group of $21-25$ years. Fresh trainees from the training centre who reported to our institute with symptoms suggestive of stress fractures were evaluated clinically and radiologically.

Clinical evaluation included a thorough history regarding the activities involved and interpretation of point tenderness at specific regions. All the trainees were particularly enquired about the habit of smoking and alcohol intake. Radiography included antero- posterior and lateral Xray projections of the involved anatomical region.

The training schedule included various forms of physical activities such as drill, short distance sprinting, long distance running, high - jump, obstacles, work- up and firing. All cases diagnosed as 


\section{ORIGINAL ARTICLE}

stress fractures were given splinting in the form of Plaster of Paris (POP) slab, except for one case of fibula stress fracture. All were refrained from physical activities and were kept on non-weight bearing mobilization with the help of a quadruple walker support for a period of 6 weeks. The patient with fibula fracture was put on a crepe bandage and was advised non-weight bearing. The POP slab was removed at 6 weeks and patients assessed clinically for point tenderness at the fracture site. Activities were gradually increased over a period of 4 weeks.

OBSERVATIONS: A total of five cases were diagnosed as stress fractures based on the clinicoradiological evaluation. The mean age was 23 years (range 22-25). The fracture distribution was as follows: tibia- 3 cases, femur and fibula- one case each. The stress fracture in the tibia was located in the lower one third in two cases and upper one third region in one case. The femoral stress fracture was at the junction of middle and distal one third. The fibula fracture was located in the mid- shaft region.

All the cases presented with the symptom of pain in the involved extremity. The pain was localized to the fracture site. The patient with femoral stress fracture also had a limp at presentation. The mean duration at presentation was 3 weeks. Pain was typically aggravated with physical activities and progressively worsened with continuation of activities. The pain was relieved with rest in all the cases. None of the trainees were smokers or alcoholics. Radiologically a faint fracture line (lucency) was visible in the case of fibular stress fracture (Fig. 1). Three cases showed heaped up callus at the site of stress fracture without clearly showing a fracture line. Periosteal reaction in the form of sclerosis was seen in one case. Table1 summarizes the observations of this study.

DISCUSSION: Stress fractures are common injuries that begin with repetitive and excessive stress on the bone. This leads to the acceleration of normal bone remodeling, the production of micro-fractures (caused by insufficient time for the bone to repair), the creation of a bone stress injury (i.e., stress reaction), and eventually, a stress fracture. ${ }^{11,12}$ Persons who participate in repetitive, high intensity training, such as athletes and military recruits, are at increased risk of developing stress fractures. Stress fractures, classically been described in military recruits and in sports persons, hence, studied and reported extensively in such populations.

The Central Industrial Security Force (CISF) came into existence in 1969, to guard the industrial establishment and protect them from crime. CISF is just a unique organization in paramilitary forces for India, which works for sea ways, airways and some of the major installations in India. A rapidly grown organization over the past four decades, the trainees receive a highly demanding physical training at the training centers. Therefore, they are equally prone for stress injuries. To the best of our knowledge no studies of stress fractures in paramilitary persons have been reported in literature so far. Hence, the present study was initiated.

We found an incidence of stress fractures as 0.25 per cent in the present study, which was similar to the incidence reported by Das and Goel in trained soldiers. ${ }^{13}$ We calculated the incidence taking into account the total number of trainees (5) who had stress fractures to the total number of trainees $(2,000)$ trained at the centre during the study period. Various studies of stress fractures in military recruits have found an incidence ranging from less than 2 per cent ${ }^{14}$ to an unusually high incidence of 31 per cent. 15

Several risk factors have been identified for stress fractures. Persons who participate in repetitive, high-intensity training such as athletes and military recruits ${ }^{16-19}$, recreational runners 


\section{ORIGINAL ARTICLE}

who average more than 25 miles per week ${ }^{17,20}$ are at increased risk of stress fractures. Poor nutrition and lifestyle habits may increase the risk of stress fracture. One study found lower 25hydroxyvitamin D levels in Finnish male military recruits with stress fractures. ${ }^{21}$ With the rising need for well-trained paramilitary forces in the country, we believe, they are equally prone for stress fractures as other persons.

In a study of 330 stress fractures in Indian recruit at a military training centre, it was found that; tibia is the commonest bone involved mostly in its upper third. ${ }^{22} \mathrm{We}$ also found the tibia as the commonest bone involved, but the lower third involvement was more ( 2 cases) as compared to the upper third (1 case).

Plain radiography should be the first imaging modality considered because of its availability and low cost. ${ }^{23}$ Plain radiography is usually negative initially but is more likely to become positive over time. ${ }^{24}$ The value of computed tomography (CT) is limited because of lower sensitivity and higher radiation exposure than other imaging modalities. ${ }^{25}$ Magnetic resonance imaging (MRI) is superior for early detection of stress injury. However, MRI may also identify reactive bone remodeling (interpreted as early stress injuries) and, therefore, should be clinically correlated for stress fracture.26, 27

With plain radiography, a faint lucency may be seen at first, although stress fractures are usually identified by subsequent indirect findings: periosteal thickening or sclerosis, cortical changes with initial decreased density ("gray cortex"), and, more commonly, later callus formation, or endosteal thickening and sclerosis. ${ }^{18,} 24$ We were able to identify the stress fracture in plain radiography on all 5 cases probably because, they presented to us at a mean period of 3 weeks. Callus was well seen in majority of our cases (Fig. 2).

Management in all the cases is essentially rest, support to the involved part and abstinence from the strenuous physical activity that caused the stress fracture.

\section{REFERENCES:}

1. Hulkko A, Orava S. Stress fractures in athletes. Int J Sports Med 1987; 8:221-6.

2. Jones BH, Harris JM, Vinh TN, et al. Exercise-induced stress fractures and stress reactions of bone: epidemiology, etiology and classification. Exerc Sports Sci Rev 1989; 17:379-422.

3. Matheson GO, Clement DB, McKenzie DC, et al. Stress fractures in athletes: a study of 320 cases. Am J Sports Med 1987; 15:46-58.

4. Belkin SC. Stress fractures in athletes. Orthop Clin North Am 1980; 11:735-42.

5. Devas MB. Stress fractures in athletes. Proc R Soc Med1969; 62:933-7.

6. Devas MB. Stress fractures in athletes. J R Coll Gen Pract 1970; 19:34-8.

7. Markey KL. Stress fractures. Clin Sports Med 1987; 6:405-26.

8. Hershman E, Mailly T. Stress fractures. Clin Sports Med 1990; 9:183-214.

9. Nattiv A, Armsey TD Jr. Stress injury to bone in the female athlete. Clin Sports Med1997; 16:197-224.

10. Bruce H. Jones, Stephen B. Thacker, Julie Gilchrist, C. Dexter Kimsey, Jr., and Daniel M. Sosin. Prevention of lower extremity stress fractures in athletes and soldiers: A systematic review. Epidemiol Rev 2002; 24:228-47.

11. Fayad LM, Kamel IR, Kawamoto S, Bluemke DA, Frassica FJ, Fishman EK. Distinguishing stress fractures from pathologic fractures: a multimodality approach. Skeletal Radiol. 2005; $34(5): 245-259$. 


\section{ORIGINAL ARTICLE}

12. Niva MH, Mattila VM, Kiuru MJ, Pihlajamäki HK. Bone stress injuries are common in female military trainees: a preliminary study. Clin Orthop Relat Res. 2009; 467(11):2962-2969.

13. Das B and Goel KK. Stress fractures in trained soldiers. Indian J Orthop. 1987; 21:162-66.

14. Brudvig TJS, Gudger TD, Obermeyer L. Stress fractures in 295 trainees: a one year study of incidence as related to age, sex and race. Milit Med 1983; 148:666-7.

15. C.Milgrom, M. Giladi, M. Stein, H. Kashtan, J.Y. Margulies, R. Chisin, R. Chisin, R. Steinberg, Z. Aharonson. Stress fractures in military recruits: A prospective study showing an unusually high incidence. J Bone Joint Surg 1985; 67(B):732-35.

16. Brukner P, Bradshaw C, Khan KM, White S, Crossley K. Stress fractures: a review of 180 cases. Clin J Sport Med. 1996; 6(2):85-89.

17. Matheson GO, Clement DB, McKenzie DC, Taunton JE, Lloyd-Smith DR, MacIntyre JG. Stress fractures in athletes. A study of 320 cases. Am J Sports Med. 1987; 15(1):46-58.

18. Ohta-Fukushima M, Mutoh Y, Takasugi S, Iwata H, Ishii S. Characteristics of stress fractures in young athletes under 20 years. J Sports Med Phys Fitness. 2002; 42(2):198-206.

19. Lappe J, Davies K, Recker R, Heaney R. Quantitative ultrasound: use in screening for susceptibility to stress fractures in female army recruits. J Bone Miner Res. 2005; 20(4):571578.

20. Clement DB, Ammann W, Taunton JE et al. Exercise-induced stress injuries to the femur. Int J Sports Med. 1993; 14(6):347-352.

21. Ruohola JP, Laaksi I, Ylikomi T et al. Association between serum $25(\mathrm{OH}) \mathrm{D}$ concentrations and bone stress fractures in Finnish young men. J Bone Miner Res. 2006; 21(9):1483-1488.

22. Khanna SK and Rao RP. Stress fractures among recruits. Med J Armed Forces 1982; 38:5-8.

23. Daffner RH, Weissman BN, Bennett DL et al. Expert Panel on Musculoskeletal Imaging. ACR Appropriateness Criteria stress/insufficiency fracture, including sacrum, excluding other vertebrae. Reston, Va.: American College of Radiology; 2008.

http://www.guideline.gov/content.aspx?id=13668. Accessed March 10, 2010.

24. Ishibashi Y, Okamura Y, Otsuka H, Nishizawa K, Sasaki T, Toh S. Comparison of scintigraphy and magnetic resonance imaging for stress injuries of bone. Clin J Sport Med. 2002; 12(2):79-84.

25. Gaeta M, Minutoli F, Scribano E et al. CT and MR imaging findings in athletes with early tibial stress injuries: comparison with bone scintigraphy findings and emphasis on cortical abnormalities. Radiology. 2005; 235(2):553-561.

26. Batt ME, Ugalde V, Anderson MW, Shelton DK. A prospective controlled study of diagnostic imaging for acute shin splints. Med Sci Sports Exerc. 1998; 30 (11):1564-1571.

27. Bergman AG, Fredericson M, Ho C, Matheson GO. Asymptomatic tibial stress reactions: MRI detection and clinical follow-up in distance runners. AJR Am J Roentgenol. 2004; 183(3):635638. 
ORIGINAL ARTICLE

\begin{tabular}{|l|l|l|l|l|l|}
\hline $\begin{array}{l}\text { Case } \\
\text { No. }\end{array}$ & $\begin{array}{l}\text { Age } \\
\text { (Years) }\end{array}$ & $\begin{array}{l}\text { Time at } \\
\text { Presentatio } \\
\text { (Weeks) }\end{array}$ & $\begin{array}{l}\text { Anatomical site of } \\
\text { Involvement }\end{array}$ & Symptoms & $\begin{array}{l}\text { Radiological } \\
\text { Features }\end{array}$ \\
\hline 1 & 22 & 3 & Upper third tibia & Pain & Callus \\
\hline 2 & 22 & 2 & Lower th ird tibia & Pain & Periosteal sclerosis \\
\hline 3 & 23 & 3 & Lower third tibia & Pain & Callus \\
\hline 4 & 23 & 3 & Fibula mid-shaft & Pain & Lucent fracture line \\
\hline 5 & 24 & 3 & Femur lower third & Pain, limp & Callus \\
\hline
\end{tabular}

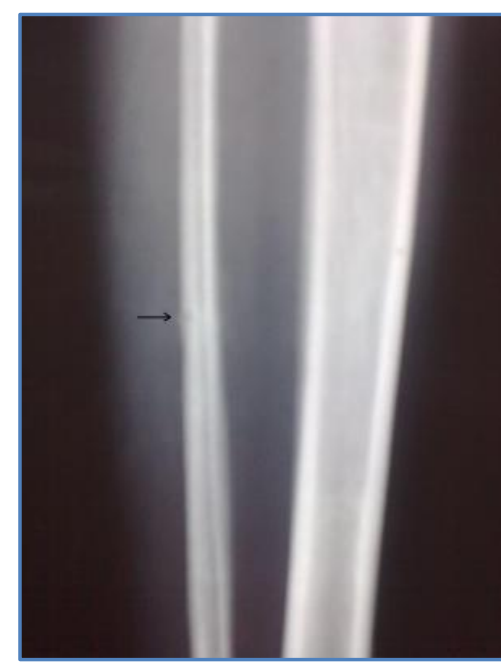

Fig. 1: Case of stress fracture of fibula showing a lucent incomplete fracture line (Arrow).

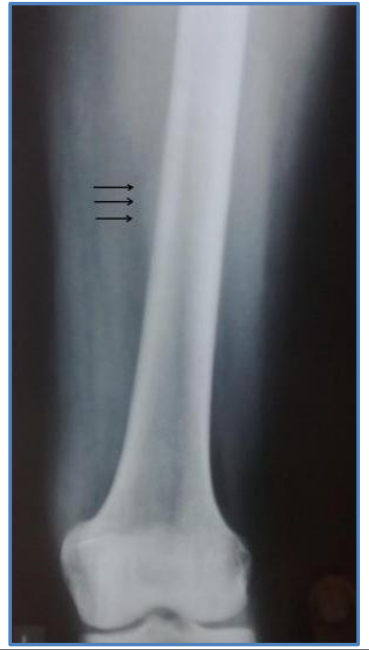

Fig. 2: Stress fracture at the junction of middle and lower third of femur showing heaped up callus (Arrow) without a fracture line.

\section{AUTHORS:}

1. Prasanna C.

2. Vijay Baba N.

3. Rajinikanth S.

\section{PARTICULARS OF CONTRIBUTORS:}

1. Assistant Professor, Department of Orthopaedics, PSGIMS \& R, Coimbatore.

2. Assistant Professor, Department of Orthopaedics, Tagore Medical College and Hospital, Chennai.

3. Consultant Orthopaedic Surgeon, Department of Orthopaedics, Chennai.

\section{NAME ADDRESS EMAIL ID OF THE} CORRESPONDING AUTHOR:

Dr. Prasanna C, Assistant Professor, Department of Orthopaedics, PSGIMS \& R, Peelamedu, Coimbatore - 641004, Tamilnadu. E-mail: prasannapgi@hotmail.com

Date of Submission: 04/02/2014. Date of Peer Review: 05/02/2014. Date of Acceptance: 18/02/2014. Date of Publishing: 05/03/2014. 